\title{
Human impact on tundra environment at the Ny-Ålesund Station, Svalbard
}

\author{
ANNA JADWIGA KRZYSZOWSKA
}

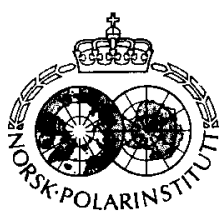

Krzyszowska, A. J. 1989: Human impact on tundra environment at the Ny-Ålesund Station, Svalbard. Polar Research 7, 119-131.

Studies were performed in Ny-Ålesund, Spitsbergen, in June and July 1986 in order to gain an insight into the effect of activities of the polar research station on the nearby environment. It was found that chemical and mechanical factors were the most detrimental to the tundra environment. Fuel oil spills $\left(110 \mathrm{~m}^{3}\right.$ in 1986), which spread via surface and ground waters, were the most damaging of the chemical factors. Domestic sewage polluted the waters of Kolhamna Bay within an area of only 0.5 ha around its outlet in the sea. Vehicles and trampling caused mechanical damage inducing destruction of plant cover and changes in the ground structure; it modified ground moisture, bulk density and depth to the permafrost. The area degraded by human activity in the vicinity of the Ny-Ålesund Research Station comprised 45 ha. The human impact around the polar station could be lessened by providing an alarm system to detect leaks and safety embankments around the oil tanks and pipelines, utilizing a settling tank for sewage, providing a simple incinerator for solid wastes, and instructing the inhabitants how to minimise impact on the environment.

Anna Jadwiga Krzyszowska, Department of Polar Research, Institute of Ecology, Polish Academy of Sciences, Dziekanow Lesny, 05-092 Lomianki, Poland; June 1988 (revised May 1989).

Multi-faceted studies of the effects of polar stations on arctic tundra ecosystems are scarce. The available literature mainly describes the functioning of these stations, i.e. water and sewage management (Egan, Pavitt \& Wiedeman 1973; Heuchert 1974; Cameron, Christensen \& Gamble 1977; Johnson 1977), disposal of wastes (Grainge \& Shaw 1971; Straughn 1972; Heinke \& Deans 1973), and fuel management (Engelhardt 1985). Some papers are concerned only with certain tundra-degrading factors such as mechanical destruction of tundra surface, or oil pollution in soil and water. In the vicinity of the Ny-Ålesund Research Station, some investigations were made about the revegetation processes of plants after mechanical disturbances (Klokk \& Rønning 1987).

Complex studies of the influence of a polar station on the environment have been performed in the vicinity of the Polish Polar Station in Hornsund, Spitsbergen (Krzyszowska 1985, 1986). In the first stage of these studies, the amount of materials supplied to the station and utilized there was determined; in the second stage, the dissemination of the different types of pollutants into the tundra was estimated. The present studies were aimed at determining the amounts of solid, liquid, and gaseous wastes reaching the environment, as well as at estimating the degree of tundra degradation in the vicinity of the Norwegian Research Station at Ny-Ålesund, Spitsbergen.

\section{The environment of $\mathrm{Ny}$-Ålesund}

$\mathrm{Ny}$-Ålesund is situated on a series of elevated sea terraces (Repp 1979) with soil at an early stage of development (Baranowski 1977; Szerszen 1965; Tedrow 1973; Plichta 1977). On the higher sea terraces, depending on the soil $\mathrm{pH}$, there is either a lime-demanding, moderate-snowbed environment (Luzulion arcticae - Elvebakk 1985) with Saxifraga oppositifolia and Cetraria delisei (Brattbakk 1981), or an acidophilous moderatesnowbed environment (Luzulion arcuate Elvebakk 1985) with Luzula confusa and lichens (Brattbakk 1981). At more wet sites, mosses and especially the grass, Deschampsia alpina, are dominant.

Studies were carried out near the buildings and cabins of the $\mathrm{Ny}-\AA \AA$ Alesund settlement $\left(78^{\circ} 55^{\prime} \mathrm{N}\right.$, $11^{\circ} 56^{\prime} \mathrm{E}$, Kongsfjord, Brøgger Peninsula) during June and July 1986 . Ny-Ålesund is a post-mining 
settlement where a research station of the Norwegian Polar Research Institute has operated since 1968. The mining activities were carried out from 1916 until 1963 with some breaks (Berg \& Wahl 1982). The remnants of the coal mining activities include tailings and excavations, and railroads and roads cover about 33 ha. At the present time, the population of $\mathrm{Ny}$-Ålesund varies from an average of 10 persons during the winter to about 100 persons during the summer. There are 39 small buildings or complexes, of which 8 are not used at present. Fuel is stored in two tanks $\left(1,100 \mathrm{~m}^{3}\right.$ total capacity), and it is led via a pipeline $(600 \mathrm{~m}$ in length) to the power station and to the harbour for refueling ships.

\section{Methods}

The pollution sources in the vicinity of the $\mathrm{Ny}$ Ålesund station include fuel oil spills, products of fuel burning at the power station, domestic sewage carried through sewage pipes directly to the sea, and refuse (Fig. 1).

Fuel oil content in water was determined at 30 sampling sites; the analyses were carried out at the

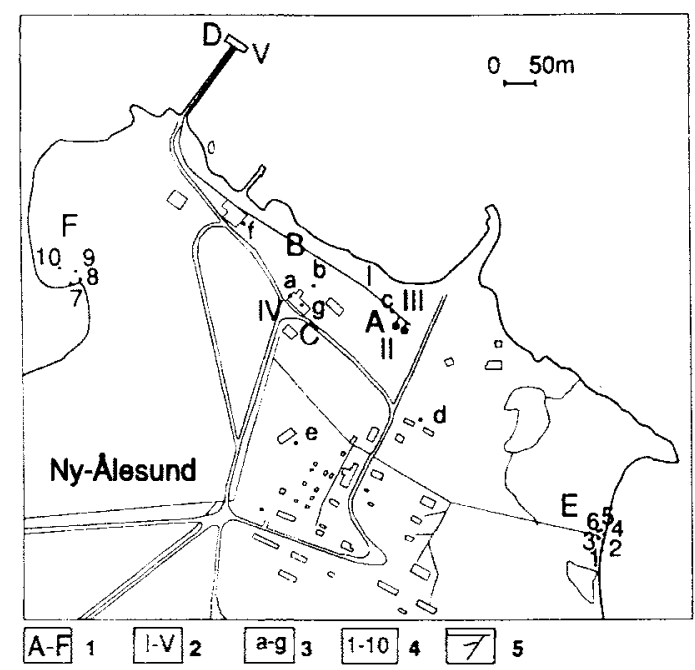

Fig. 1. Sources of pollution in the vicinity of the Ny-Âlesund Research Station, 1986. 1. Sources of pollution: A - oil tanks: $B$ - oil pipeline; $C$ - power station: $D$ - harbour; $E$ - outlet of sewage: $F-$ dump of solid refuse. 2 . Oil spills: $I-90 \mathrm{~m}^{3}$ : II $15 \mathrm{~m}^{3}$ : III $-1 \mathrm{~m}^{3}$; IV. V - not determined. 3. Sites of dustfall collectors. 4. Sites of soil sample collection for $\mathrm{pH}$. conductance and moisture determinations. 5. Utilidors. laboratory of the Norwegian Institute for Water Research, Oslo. Water samples were stored refrigerated until extraction with $\mathrm{n}$-hexane $(50 \mathrm{ml}$ per $1 \mathrm{dm}^{3}$ of sample). Fuel oil concentration in the extract was estimated using a Perkin-Elmer spectroflorometer. The content of fuel oil in soil was determined for 25 surface samples (collected at $0-5 \mathrm{~cm}$ depth) and for 18 soil sampling profiles, with samples taken at depths of $2,5,10,18$, $20,35,40$, and $60 \mathrm{~cm}$ with a manual probe. Oil contents in soil were determined by a semi-micro extraction method with n-hexane (Hermanowicz et al. 1976). In the vicinity of sources of chemical pollution, 10 soil samples were collected for $\mathrm{pH}$, conductivity, and moisture determination (Bialousz \& Sklodowski 1979).

The dustfall was estimated by exposing glass traps for 49 days $2-3 \mathrm{~m}$ above ground level. The amount of gaseous products discharged from the chimneys of the power station was measured five times using a hand pump and Draeger indicator tubes for $\mathrm{SO}_{2}, \mathrm{CO}, \mathrm{CO}_{2}$, and nitrogen oxides (Juda \& Chròsciel 1974).

The domestic sewage produced was measured during three 24 hour periods. The amount of refuse produced in the kitchen and living quarters during 24 hours was weighed four times. For 33 surface water samples and for 13 domestic sewage samples, the following measurements were made: temperature, $\mathrm{pH}$, conductivity, ammonium nitrogen, nitrate nitrogen, nitrite nitrogen, orthophosphate, alkalinity, total hardness, calcium, magnesium, sulphate, and chloride (Golterman 1978; Markowicz \& Pulina 1979). The sewage was sampled for a period of a few days: in the morning, before and after breakfast; in the midday, before and after lunch; in the evening after dinner; in the night. Thirty surface sea water samples were collected around the sewage outlet. Sea water samples were collected with a Nansen cylinder from $1.3 \mathrm{~m}$ depth at $15 \mathrm{~m}$ distance from the coast line and from $2.5 \mathrm{~m}$ depth at $50 \mathrm{~m}$ distance from the coast line. In the sea water samples, the following determinations were made: temperature, $\mathrm{pH}$, conductivity, salinity, nitrate nitrogen, nitrite nitrogen, ammonium nitrogen, orthophosphate, and alkalinity (Golterman 1978; Trzosinska et al. 1980). Salinity and conductivity were measured with a Yellow Springs Instrument model 33, series 128.2 conductivity-meter; $\mathrm{pH}$ was determined using a Radiometer PHM $80 \mathrm{pH}$ meter. Nitrogen species and orthophosphate were assayed spectrophotometrically using a Zeiss 10 
spectrophotometer. The total count of bacteria in domestic sewage and coastal waters near the sewage outlet was determined at 6 sampling sites. At each site, two water samples were taken and each was analysed in duplicate. Bacteria were cultured on an agar medium and the bacterial count was made after 48 hours of incubation at $37^{\circ} \mathrm{C}$. To estimate the spreading of domestic sewage into coastal waters, fluorescein was added on five occasions to sewage, and the spread of the dye in the sea was measured after $3,10,40$, and 90 minutes.

Mechanical destruction was determined in 7 transects crossing roads and pathways. The intensity of use for the roads and pathways was as follows: transects no. 1, 6, and 7-trampling and permanently used by vehicles; transects no. 3 and 4 - trampling and used by vehicles sometimes; transects no. 2 and 5 -trampling only. The roads are used by vehicles including light lorries, tractors, strippers, and loaders. For each transect, the width of the road and the depth of ruts were measured; moreover, two samples of the ground from the road and two samples of the ground adjacent to the road were taken for particle size analysis. Furthermore, the depth of permafrost was measured at intervals of $50-70 \mathrm{~cm}$ between sampling sites. Within each transect, at four sampling sites, the bulk density of soil was determined by the method of cylinder sampling (Falkiewicz \& Kowalski 1957) and the moisture in the 0-10 $\mathrm{cm}$ soil layer was measured (Bialousz \& Sklodowski 1979). Phytosociological records were made for transects 1,2 , and 3 with the co-operation of Arve Elvebakk from the University of Troms $\varnothing$. Vascular plants nomenclature is from Rønning (1979), for mosses from Nyholm (1975-1979), and for lichens from Nowak (1965).

\section{Results and discussion}

In order to evaluate environmental degradation in the vicinity of the Research Station at $\mathrm{Ny}$ Ålesund, estimates of the amount of fuel oil which leaked from damaged pipelines and oil tanks were obtained, and the amounts of domestic sewage and refuse produced were measured. Subsequently, the spread of the different pollutants was evaluated. Tundra surface degradation caused by mechanical destruction (travelling vehicles, trampling) was also assessed.

\section{Pollution related to fuel oil spills}

The sources of the fuel oil spills were damaged pipelines and oil tanks, refueling ships in the harbour, spills and cleaning of engines around the power station (Fig. 1). There was an exceptionally high level of pollution caused by severe damage to pipelines and oil tanks. It was estimated that about $110 \mathrm{~m}^{3}$ of petroleum-derived fuel leaked into the environment around the $\mathrm{Ny}$-Ålesund station from November 1985 until July 1986 (Geir Gabrielsen pers. comm.).

The spread of fuel oil into the environment depends on several factors: the type of ground surface, the hydrological conditions (Fig. 2), the nature and physical composition of the soil, and the presence of plant cover. Spills from oil tanks caused the most severe oil pollution of soil and waters (Fig. 1, no. II). The area affected by the oil spill extended consistently downslope due to slope, coarse texture, and shallow permafrost depth. In order to reduce spreading of the spilled fuel oil during spring thaw, traps were placed in streams and ponds to retain the surface layer of oil.

Consistently high oil concentrations in water occurred in a pond below the oil tanks (Fig. 2, no. 1); the concentration was $60,400 \mathrm{ppm}$ on 18 June 1986 (Table 1, sample no. 1). After three weeks, the concentration decreased by $30 \%$
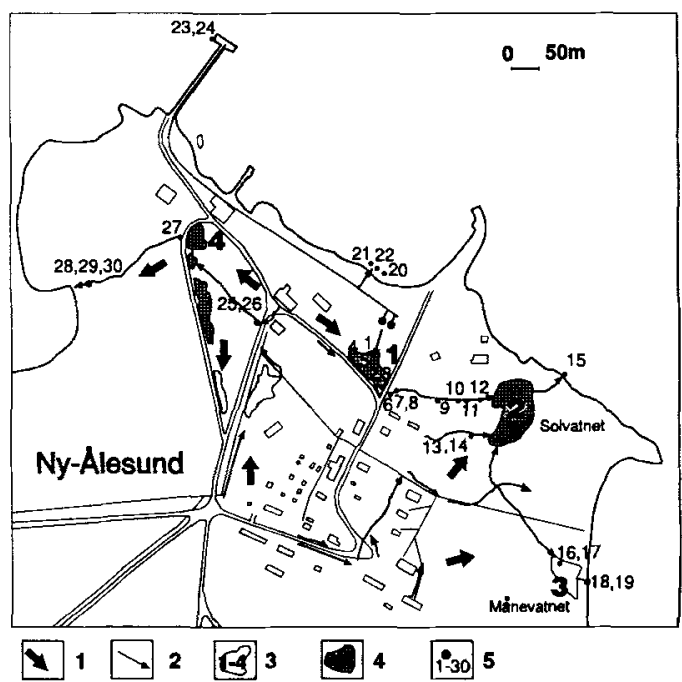

Fig. 2. Hydrologic conditions (18 June-26 June 1986) in the vicinity of the Ny-Ålesund Research Station. 1. Main direction of flowing water; 2. Streams; 3. Main ponds; 4. Oil-polluted ponds; 5 . Sites of water sample collection for oil determination. 
Table 1. Oil content (ppm) in waters in the vicinity of the $\mathrm{Ny}$-Älesund Polar Station; sampling station locations shown in Fig. 2.

\begin{tabular}{|c|c|c|c|c|}
\hline $\begin{array}{l}\text { Sampling } \\
\text { station }\end{array}$ & Location of sampling stations (Fig. 2) & $\begin{array}{l}\text { Flow rate } \\
\mathrm{dm}^{3} / \mathrm{min}\end{array}$ & $\begin{array}{l}\text { Date } \\
1986\end{array}$ & $\begin{array}{l}\text { Content of fucl oil in } \\
\text { water samples ppm }\end{array}$ \\
\hline 1 & pond (no. 1) beneath oil tanks & & 18.06 & 60,400 \\
\hline 2 & & & 26.06 & 53,700 \\
\hline 3 & & & 7.07 & 17,700 \\
\hline 4 & pools near pond (no. 1) & & 26.06 & 7.8 \\
\hline 5 & & & 7.07 & 225 \\
\hline 6 & bencath pond (no. 1). beginning of stream & 120 & 18.06 & 308,200 \\
\hline 7 & $15 \mathrm{~m}$ from the beginning of stream & 60 & 26.06 & 3.1 \\
\hline 8 & & 180 & 7.07 & 0.1 \\
\hline 9 & stream bend. stagnant water & & 7.07 & 2.7 \\
\hline 10 & stream, at oil trap & 60 & 7.07 & 30 \\
\hline 11 & oi] trap & & 26.06 & 620,800 \\
\hline$\cdots$ & access of stream to Solvatnet pond (no, 2) & 30 & 7.07 & 6.1 \\
\hline 13 & (n) & 5 & 26.06 & 0.1 \\
\hline 14 & & 0.5 & 7.07 & 1.2 \\
\hline 15 & outflow from Solvatnet pond (no. 2) & 115 & 26.06 & 0.1 \\
\hline 16 & Mănevatnet pond (no. 3) & & 21.06 & 0.1 \\
\hline 17 & & & 7.07 & 0.1 \\
\hline 18 & outflow from Mánevatnet pond (no. 3 ) into the sea & 180 & 18.06 & 0.1 \\
\hline 19 & & 300 & 26.06 & 0.4 \\
\hline 20 & sea water within the zone of breakers at the & & 21.06 & 1,340 \\
\hline 21 & maximum tide & & 26.06 & 19.7 \\
\hline 22 & & & 7.07 & 1.2 \\
\hline 23 & sea water in the harbour & & 21.06 & 0.2 \\
\hline 24 & & & 7.07 & 2.7 \\
\hline 25 & stream & 5 & 26.06 & 0.3 \\
\hline 26 & & 30 & 7.07 & 6.4 \\
\hline 27 & stream & 17.5 & 7.07 & 0.1 \\
\hline 28 & outflow into the sea & 1.000 & 18.06 & 0.2 \\
\hline 29 & & 1.500 & 26.06 & 0.1 \\
\hline 30 & & 500 & 7.07 & not defected \\
\hline
\end{tabular}

(Table 1, sample no. 3). The highest concentration of oil was measured in the water flowing to the Solvatnet pond from the outflow of the pond beneath the tank $(308,200 \mathrm{ppm}$ oil on 18 June 1986). The oil decreased quickly after the installation of the oil traps; the oil concentration in the oil traps was as high as $620,800 \mathrm{ppm}(26$ June). The concentration decreased to $6.1 \mathrm{ppm}$ by 7 July in the influent stream to the Solvatnet pond (Table 1, sample no. 12). The oil concentration also fell abruptly in coastal waters, near the main spill of fuel oil from the pipeline (Fig. 1, no. I); for example, during sea ice thawing, the fuel oil content in the zone of breakers was 1,340 ppm, and after three weeks it dropped to $1.2 \mathrm{ppm}$ (Table 1, samples no. 20, 21, 
and 22). Concentration of the $\mathrm{n}$-hexane-extracted substances in surface waters near the research station decreased with the distance from the pollution sources (Table 1). Fuel oil accumulated in the ponds (Fig. 2, no. 1, 2, and 3) located below the main oil spill sources to such an extent that stream water outflowing from the Solvatnet pond to the sea contained only small concentrations of oil, if any (Table 1; Fig. 2).

At snow melt, fuel oil spread via surface waters tended to accumulate in the vegetation covering the surface soil layer $(0-10 \mathrm{~cm}$ depth). The total area affected was $16,700 \mathrm{~m}^{2}$ (Fig. 3). Maximum pollution of the soil surface layer occurred in the vicinity of the oil tanks and pipelines, amounting to $15,100 \mathrm{mg}$ of the n-hexane-extractable substances per $100 \mathrm{~g}$ soil D.M. (Table 2). At these sites, the pollution penetrated to $50 \mathrm{~cm}$ depth (Table 3, profile 26). The belt of polluted soil was situated mainly along the streams; the concentration of pollutants ranging from 51.5 to $6,230 \mathrm{mg} / 100 \mathrm{~g}$ soil D.M. (Table 2 ; Fig. 3 ). The fuel oil content dropped (Table 3 ) with increasing soil depth; this decrease was greatest at sites with vegetative cover, absorbing $85 \%$ to $100 \%$ of the

Table 2. Content of n-hexane-extracted substances in surface $5 \mathrm{~cm}$ of soil; location shown in Fig. 3 .

\begin{tabular}{lll}
\hline Sample & $\begin{array}{l}\text { Content of n-hexane-extracted } \\
\text { substances (mg/100g soil D.M.) }\end{array}$ & $\begin{array}{l}\text { Moisture } \\
\%\end{array}$ \\
\hline 1 & 3,475 & 71.5 \\
2 & n.d. & 30.7 \\
3 & n.d. & 82.9 \\
4 & 11,674 & 86.6 \\
5 & n.d. & 34.6 \\
6 & n.d. & 5.8 \\
7 & 12,863 & 81.1 \\
8 & n.d. & 23.6 \\
9 & 8,833 & 80.3 \\
10 & n.d. & 32 \\
11 & n.d. & 76.9 \\
12 & 3,116 & 19.3 \\
13 & 8,820 & 78 \\
14 & 15,100 & 65.6 \\
15 & 6,230 & 57 \\
16 & n.d. & 26.7 \\
17 & 51.5 & 24.1 \\
18 & n.d. & 21.9 \\
19 & 255 & 60.5 \\
20 & 521 & 56.2 \\
21 & 11,200 & 38.5 \\
22 & 8,670 & 59.5 \\
\hline
\end{tabular}

n.d. - not detected

Nos. $4,7,9$ - plant cover samples
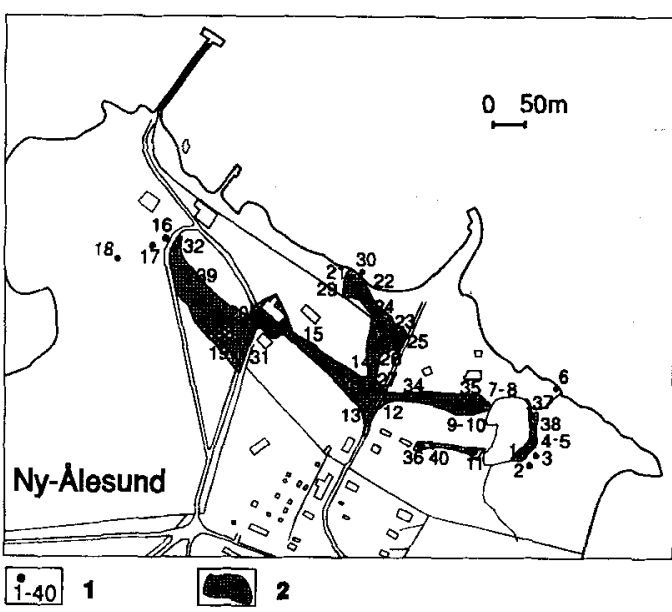

Fig. 3. Map of sample collection sites of soils polluted with fuel oil, in 1986. 1. Sites of soil sample collection; 2. Soil polluted with oil.

fuel oil (Table 3, profiles 32, 39, and 40). For example, in profile 26 (Table 3; Fig. 3), the content of $n$-hexane-extractable substances was $46 \%$ less at $7 \mathrm{~cm}$ depth compared to $2 \mathrm{~cm}$ depth; when compared with the previous depth, at $18 \mathrm{~cm}$ depth it was $36 \%$, at $35 \mathrm{~cm}$ depth $27 \%$, and at $50 \mathrm{~cm}$ depth $2 \%$. Soil pollution from fuel oil persists for long periods due to the slow degradation and low solubility and volatility of hydrocarbons and their derivatives in cold climates (Moore \& Phillips 1975; Atlas \& Busdosh 1976; Verstraete et al. 1976; Doane 1977; Sextone \& Atlas 1977). Fuel oil spills have been found to destroy the plant cover (Bliss 1970; Wein \& Bliss 1973; Raisbeck \& Mohtadi 1974; Getman 1977). It seems that even the greatest fuel oil spill into the sea (Fig. 1, no. I) which occurred at $\mathrm{Ny}$-Ålesund was less harmful than the fuel oil spills in the tundra since the action of breakers disseminated the pollution.

Solid and gaseous products of fuel oil combustion including carbon monoxide, carbon dioxide, sulphur dioxide, and nitrogen oxides were produced in small amounts by the power station and only polluted its immediate vicinity. Likewise, the dustfall 'was heaviest close to the power station, amounting to $0.47-0.59 \mathrm{~kg} / 100 \mathrm{~m}^{2}$ per month. Within a greater distance (about $250 \mathrm{~m}$ westward and $500 \mathrm{~m}$ eastward from the power station), the dustfall was only $0.05-0.21 \mathrm{~kg}$ / $100 \mathrm{~m}^{2}$ per month; this corresponds to the mean natural dustfall in the coastal zones (Manecki 1978). 
124 A. J. Krzyszowska

Table 3. Content of n-hexane-extracted substances in soil profiles; sampling locations shown in Fig. 3.

\begin{tabular}{|c|c|c|c|}
\hline $\begin{array}{l}\text { No. of } \\
\text { profile }\end{array}$ & $\begin{array}{l}\text { Depth of sample } \\
\text { collection } \\
\mathrm{cm}\end{array}$ & $\begin{array}{l}\text { Content of } \mathrm{n} \text {-hexane } \\
\text { extracted substances } \\
\mathrm{mg} / 100 \mathrm{~g} \text { of soil D.M. }\end{array}$ & $\begin{array}{l}\text { Moisture } \\
\%\end{array}$ \\
\hline 23 & $\begin{array}{c}0-5 \\
5-20 \\
20-37\end{array}$ & $\begin{array}{l}9,793 \\
1,879 \\
1,149\end{array}$ & $\begin{array}{l}25 \\
17.4 \\
13.2\end{array}$ \\
\hline 24 & $\begin{array}{l}0-2 \\
2-5 \\
5-18\end{array}$ & $\begin{array}{r}15,854 \\
428 \\
222\end{array}$ & $\begin{array}{l}70.6 \\
12.6 \\
12\end{array}$ \\
\hline 25 & $\begin{array}{l}0-2 \\
2-9\end{array}$ & $\begin{array}{l}1,332 \\
1,195\end{array}$ & $\begin{array}{l}20.8 \\
11.7\end{array}$ \\
\hline 26 & $\begin{array}{c}0-2 \\
2-7 \\
7-18 \\
18-35 \\
35-50\end{array}$ & $\begin{array}{l}5,232 \\
3,569 \\
2,624 \\
2,066 \\
2,022\end{array}$ & $\begin{array}{r}7.7 \\
14.3 \\
7.8 \\
5.8 \\
9.5\end{array}$ \\
\hline 27 & $\begin{array}{c}0-2 \\
2-5 \\
5-18 \\
18-36 \\
36-50\end{array}$ & $\begin{array}{r}55,408 \\
52,403 \\
1.973 \\
852 \\
1,197\end{array}$ & $\begin{array}{l}73.3 \\
70.8 \\
31.5 \\
32.5 \\
28.7\end{array}$ \\
\hline 28 & $\begin{array}{l}0-2 \\
2-5 \\
2-12 \\
12-28\end{array}$ & $\begin{array}{r}2,236 \\
735 \\
351 \\
97\end{array}$ & $\begin{array}{r}74.2 \\
7.7 \\
51.2 \\
10.8\end{array}$ \\
\hline 29 & $\begin{array}{c}0-2 \\
2-5 \\
5-10 \\
10-20\end{array}$ & $\begin{array}{r}5,009 \\
1,331 \\
202 \\
541\end{array}$ & $\begin{array}{r}12.4 \\
25.2 \\
12.1 \\
9.1\end{array}$ \\
\hline 30 & $\begin{array}{c}0-2 \\
2-5 \\
5-15 \\
15-27\end{array}$ & $\begin{array}{l}129 \\
402 \\
382 \\
290\end{array}$ & $\begin{array}{l}5.4 \\
6.4 \\
9.9 \\
7.2\end{array}$ \\
\hline 31 & $\begin{array}{l}0-2 \\
2-5\end{array}$ & $\begin{array}{l}21.904 \\
14,400\end{array}$ & $\begin{array}{l}35.4 \\
31.1\end{array}$ \\
\hline 32 & $\begin{array}{l}0-5 \\
5-60\end{array}$ & $\begin{array}{l}55.408 \\
\text { n.d. }\end{array}$ & 83.9 \\
\hline 33 & $\begin{array}{l}0-2 \\
2-5 \\
5-13\end{array}$ & $\begin{array}{r}1,447 \\
916 \\
36\end{array}$ & $\begin{array}{l}54.3 \\
74.4 \\
15.7\end{array}$ \\
\hline 34 & $\begin{array}{c}0-2 \\
2-5 \\
5-7 \\
7-27 \\
27-52\end{array}$ & $\begin{array}{r}16.155 \\
1.633 \\
129 \\
152 \\
\text { n.d. }\end{array}$ & $\begin{array}{l}77.2 \\
21 \\
19.3 \\
14.9\end{array}$ \\
\hline 35 & $\begin{array}{c}0-6 \\
6-9 \\
9-39 \\
39-47\end{array}$ & $\begin{array}{r}46,522 \\
1,334 \\
3.501 \\
156\end{array}$ & $\begin{array}{l}67.5 \\
88.8 \\
74 \\
41.7\end{array}$ \\
\hline
\end{tabular}


Table 3-continued.

\begin{tabular}{|c|c|c|c|}
\hline $\begin{array}{l}\text { No. of } \\
\text { profile }\end{array}$ & $\begin{array}{l}\text { Depth of sample } \\
\text { collection } \\
\mathrm{cm}\end{array}$ & $\begin{array}{l}\text { Content of n-hexane } \\
\text { extracted substances } \\
\mathrm{mg} / 100 \mathrm{~g} \text { of soil D.M. }\end{array}$ & $\begin{array}{l}\text { Moisture } \\
\%\end{array}$ \\
\hline \multirow[t]{3}{*}{36} & $0-2$ & 3,125 & 26.9 \\
\hline & $2-6$ & 49 & 8.7 \\
\hline & $6-30$ & 161 & 13.1 \\
\hline \multirow[t]{3}{*}{37} & $0-7$ & 60,063 & 83 \\
\hline & $7-15$ & 101 & 92.6 \\
\hline & $15-28$ & n.d. & 85.4 \\
\hline \multirow[t]{3}{*}{38} & $0-5$ & 3,605 & 90.7 \\
\hline & $5-15$ & 1,389 & 86.5 \\
\hline & $15-24$ & 1,807 & 87.7 \\
\hline \multirow[t]{2}{*}{39} & $0-5$ & 82,458 & 87.6 \\
\hline & $6-60$ & n.d. & \\
\hline \multirow[t]{2}{*}{40} & $0-5$ & 1,059 & 79.9 \\
\hline & $5-60$ & n.d. & \\
\hline
\end{tabular}

n.d. - not detected

\section{Pollution of the environment by domestic sewage and solid waste}

In the summer of 1986 , the mean amount of domestic sewage reaching the sea was about $209 \mathrm{dm}^{3}$ per head per day; this is comparable to the amounts of domestic sewage produced at other polar stations (Table 4). The chemical composition of domestic sewage varied throughout a $24 \mathrm{~h}$. period, depending on the usage of washing and other cleaning agents. The content of ammonium nitrogen in sewage was particularly high in the early morning hours (about $\left.30 \mathrm{mg} \times \mathrm{dm}^{-3}\right)$, as was the sulphate concentration (greater than $300 \mathrm{mg} \times \mathrm{dm}^{-3}$ ); this sometimes exceeded the 'Norwegian Recommended Level
For Nontreated Industrial Waste Waters'. The high concentration of nitrate nitrogen (up to $2 \mathrm{mg} \times \mathrm{dm}^{-3}$ ) even exceeded that found for greatly polluted domestic sewage in the U.S.A. (Table 5). Sea water samples collected near the bottom ( $15 \mathrm{~m}$ from the coast line at $1.3 \mathrm{~m}$ depth and $50 \mathrm{~m}$ offshore at $2.5 \mathrm{~m}$ depth) did not contain increased concentrations of nutrients when compared to unpolluted samples from Kolhamna Bay, taken at a distance of $200 \mathrm{~m}$ from the coast line (Table 5). Salinity was characteristic of freshwater-fed shallow bays (Urbanski, Neugebauer \& Sajcer 1980). According to microbiological tests of domestic sewage, the total bacterial count was up to $3.7 \times 10^{6}$ per $1 \mathrm{~cm}^{3}$ of sewage after $48 \mathrm{hrs}$. incubation at $37^{\circ} \mathrm{C}$. The maximum bac-

Table 4. Amounts of sewage produced at some Arctic Stations.

\begin{tabular}{llc}
\hline Station & $\begin{array}{l}\text { Amount of sewage } \\
\mathrm{dm}^{3} / \text { head } \times 24 \mathrm{hrs} .\end{array}$ & Reference \\
\hline $\begin{array}{l}\text { American Stations, } \\
\text { Alaska }\end{array}$ & 209 & Alter 1969 \\
$\begin{array}{l}\text { Construction camp, } \\
\text { Alaska } \\
\begin{array}{l}\text { Polish Polar Station, } \\
\text { Hornsund, Svalbard }\end{array}\end{array}$ & $178-318$ & Smith 1977 \\
$\begin{array}{l}\text { Norwegian Polar } \\
\text { Station, Ny-Alesund, } \\
\text { Svalbard }\end{array}$ & 42 & Krzyszowska 1985 \\
\hline
\end{tabular}




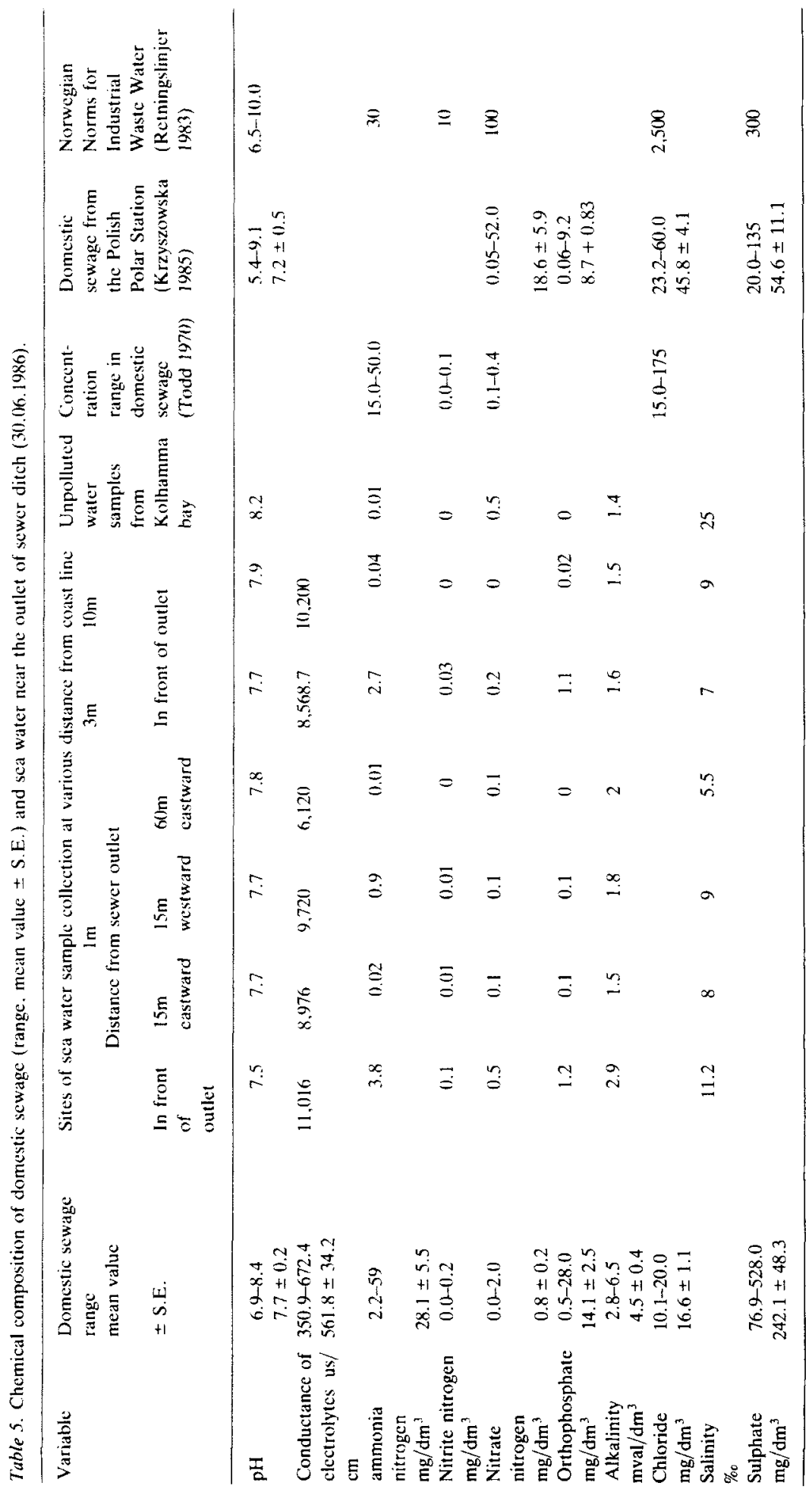


terial counts occurred within $10 \mathrm{~m}$ from the sewage outlet (total counts were 2.6 to $3.5 \times 10^{5}$ per $1 \mathrm{~cm}^{3}$ of water). As soon as the sewage entered the sea, it was diluted manyfold; for example, the ammonium nitrogen concentration dropped 4 times and the phosphate concentration decreased 2.5 times within $1 \mathrm{~m}$ of the outlet (Fig. 4). The action of breakers and wind contributed to sewage dilution. It is typical for inhabitants of the polar regions to take advantage of the diluting action of coastal waters and discharge nontreated sewage directly into the sea (Alter 1969; Hanover 1969; Budrick \& Johnson 1977; Sargent \& Scribner 1976; Smith 1977; Frearson 1983). At NyÅlesund, it was estimated that the effect of domestic sewage, measured in terms of an increase in nutrient concentrations and a drop in the salinity of Kolhamna Bay waters, extended 0.5 ha around the sewage outlet (Fig. 4).

Chemical analysis of water samples collected from local streams and pools near buildings and the solid-waste burning site had slightly increased nutrient contents compared to water supplied to the station. Around the outlet of nontreated domestic sewage (Fig. 1), a nutrient-rich microenvironment was formed. The fungus Psilocybe merdaria, which characteristically grows in nutrient-rich soils, occurred here; it has not previously been reported on Spitsbergen (Gro Gulden pers. comm.). At this site and near the solid-waste burning site, the soil displayed increased concentrations of ions compared to unpolluted soil. Solid wastes amounting to $0.5-1.2 \mathrm{~kg} /$ head per day are produced, and are brought to the burning site. This is comparable to the amount of refuse formed at other polar stations and settlements (Table 6). Much of the refuse produced at polar research stations consists of packing materials used for food and equipment during transport.

\section{Damage to the tundra surface caused by trampling and vehicles}

In the vicinity of $\mathrm{Ny}$-Ålesund, trampling and vehicles destroyed the plant cover in various locations. On roads and pathways, there were no lichens (transects 1, 2, and 3), no mosses (Aulocomnium turgidum), and certain vascular species were absent (Salix polaris, transects 2 and 3; Saxifraga oppositifolia, transects 1 and 3; Pedicularis hirsuta and Silene acualis, transects 1 and 2) (Fig. 5). This is consistent with the reports of other authors suggesting the following sequence of decreasing fragility: lichens, mosses, vascular plants (Bliss \& Wein 1972; Greller, Goldstein \& Marcus 1974; Webber \& Ives 1978). The dominant plants on abandoned roads were the grasses Deschampsia alpina and Poa arctica, forming typical tussocks. This is characteristic of grasses in their resistance to destruction (Chapin

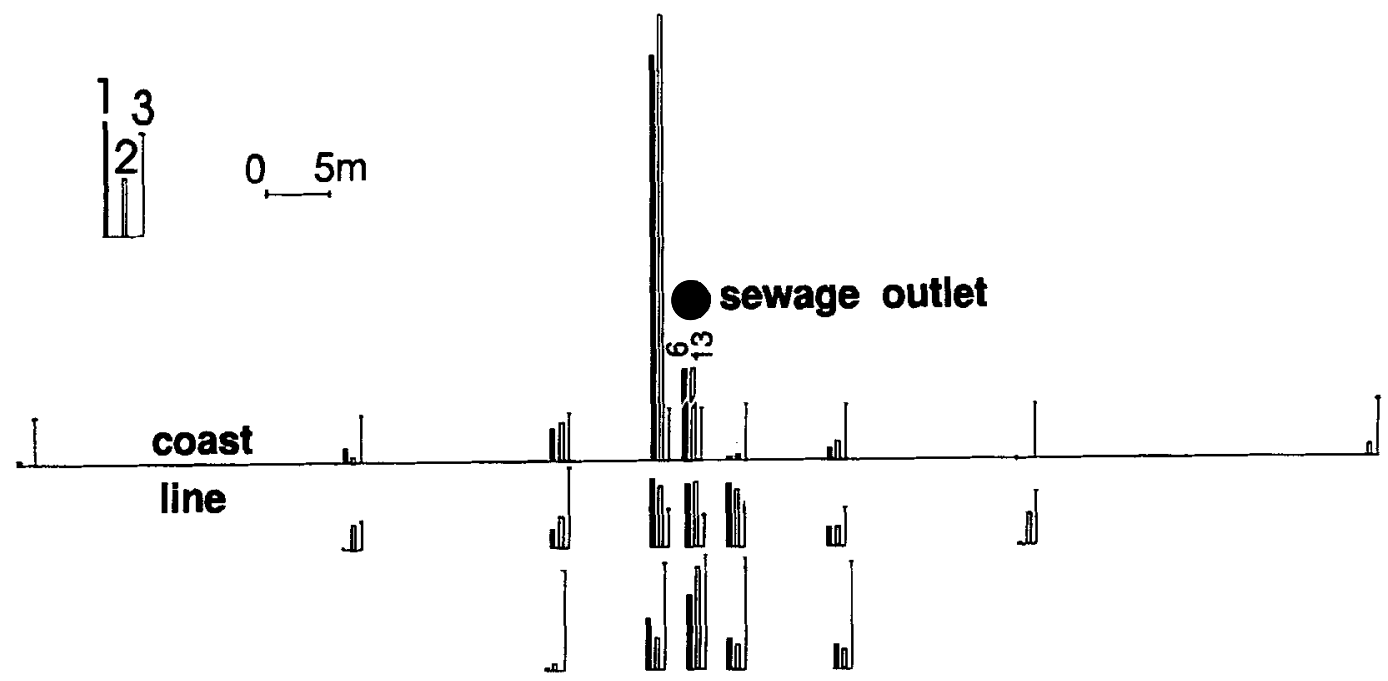

Fig. 4. Chemical analysis of seawater near sewage outlet (8 July 1986). Scale heights: $1 . \mathrm{N}_{-} \mathrm{NH}_{4}-1.0 \mathrm{mg} / \mathrm{dm}^{3} ; 2 . \mathrm{P}-\mathrm{PO}_{4}-0.5 \mathrm{mg} /$ $\mathrm{dm}^{3} ; 3$. salinity - $5 \%$. The concentrations at the sewage outlet were: $\mathrm{N}-\mathrm{NH}_{4}-24 \mathrm{mg} / \mathrm{dm}^{3} ; \mathrm{P}-\mathrm{PO}_{4}-33 \mathrm{mg} / \mathrm{dm}^{3}$. 
Table 6. Amounts of solid waste produced at some Arctic stations.

\begin{tabular}{lll}
\hline Station & $\begin{array}{l}\text { Amount of wastes } \\
\mathrm{kg} / \text { head } \times 24 \mathrm{hrs} .\end{array}$ & Reference \\
\hline $\begin{array}{l}\text { Construction Camp. } \\
\begin{array}{l}\text { Alaska } \\
\text { American stations, }\end{array}\end{array}$ & $2.3-3.6$ & Smith 1977 \\
$\begin{array}{l}\text { Alaska } \\
\text { Polish Polar } \\
\text { Station, Svalbard }\end{array}$ & 2.4 & Alter 1969 \\
$\begin{array}{l}\text { Norwegian Polar } \\
\text { Station. Svalbard }\end{array}$ & 0.1 & Krzyszowska 1986 \\
\hline
\end{tabular}

\& Shaver 1981). On roads whose soils had a higher moisture content, Phippsia algida, Deschampsia alpina, and Pottia heimii occurred.

In addition to destruction of the plant cover, trampling and vehicles also caused crumbling of the ground. The sandy fraction increased by an average of $17 \%$, while the stone fraction decreased by $60 \%$. As a result of this, the ground became more compact, the bulk density increased from $13 \%$ to $32 \%$, and the permeability was reduced up to five times. Roads without plant cover exhibited a slight increase in the permafrost thaw depth from 0.7 to $5.9 \mathrm{~cm}$ (Table 7). The degree of damage to the tundra surface depends on the duration and intensity of its exploitation,

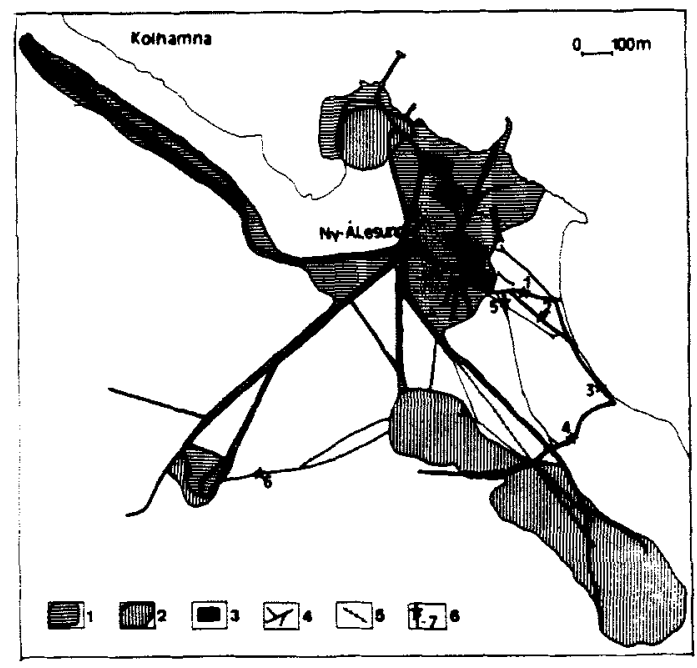

Fig. 5. The area influenced by human activity in the vicinity of the Ny-Ålesund Research Station. 1. Tundra degradation caused by present-day human activity; 2 . Tundra degradation caused by earlier coal mine activity; 3 . Barren areas, no plant cover; 4 . Roads; 5 . Abandoned railroad; 6 . Sites of soil-sampling transects across roads and paths. soil composition and humidity, and type of vegetation (Ives 1970; Rickard \& Brown 1974; Kaltenborn 1986). In the vicinity of $\mathrm{Ny}$-Ålesund, there are about $13.5 \mathrm{~km}$ of roads in various degrees of use.

\section{Final evaluation of environmental degradation in the vicinity of $N y$-Alesund}

The fragility of the tundra environment to human pressure is known to vary greatly. The reaction of different tundra types to the effects of anthropogenic factors depends on the presence, extent, and type of vegetation cover, physical and chemical properties of the ground, as well as on the local climate and hydrological conditions. According to the criteria suggested by Baab \& Bliss (1974) for the evaluation of the sensitivity of tundra to anthropogenic factors, $\mathrm{Ny}$-Ålesund should be classed among areas with medium to high susceptibility to destruction. Consistent with this classification, the most susceptible areas occur on the lowest and middle sea terraces, which have periodic ponds, wet soil, and plant cover.

The mechanical and chemical effects are detrimental to the environment (Krzyszowska 1986). With respect to the chemical factors, the greatest danger to the tundra environment was fuel oil, because of its extent and spreading via surface and ground waters. The extent of anthropogenic effects on the tundra was evaluated according to the following criteria: degree of plant cover destruction, changes in soil texture, presence of fuel oil in soil and water, and damage to the tundra surface, including that from previous coalmining activities. The area degraded by the present-day human activities comprises $45 \mathrm{ha}$, and that degraded by former mining activities covers an additional 33 ha (Fig. 5). For comparison, the area degraded by human activities at the smaller 


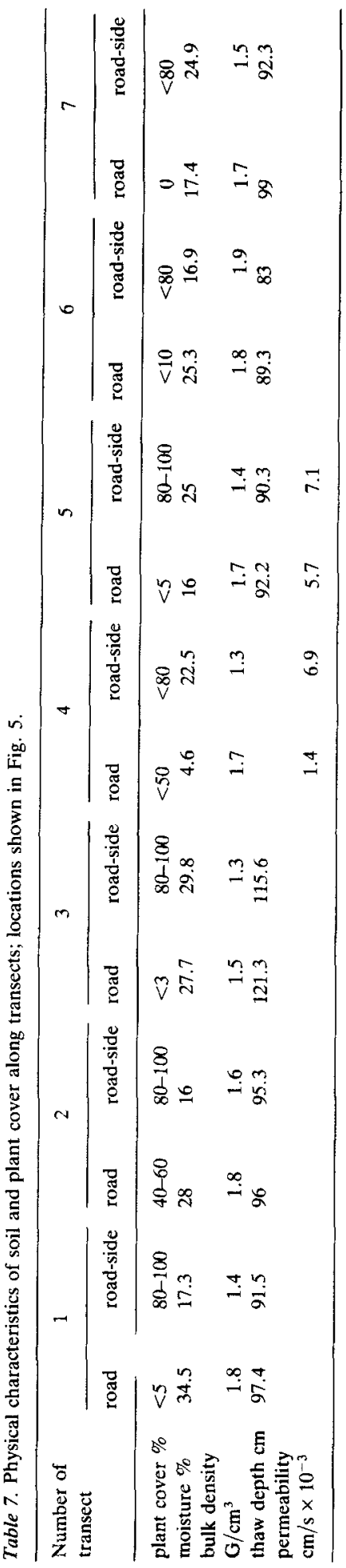

Polish Polar Station at Hornsund, Spitsbergen, comprises 3.5 ha (Krzyszowska 1985).

\section{Recommendations concerning waste management at $\mathrm{Ny}$-Ålesund}

The environmental legislation for Spitsbergen is contained in the 'Environmental Regulations for Svalbard and Jan Mayen', issued by the Norwegian Ministry of Environment. It would be appropriate for each polar station to establish more detailed regulations. This was done for the Polish Polar Station at Hornsund by the author of this article.

The following specific recommendations concerning waste management at $\mathrm{Ny}$-Ålesund are made:

1. An alarm system should be installed around the potential sources of oil spills such as oil tanks and pipelines, and safety embankments should be made around the oil tanks to prevent the spread of oil in the event of a spill.

2 . Treatment of sewage is only slightly recommended since bacteriological contamination of the Kolhamna Bay is small. It could be accomplished by a 3- or 4-chamber settling tank with an outlet into the gravel and sand of beaches below high tide line. The sediments in the settling tanks could be manually removed periodically.

3. Solid wastes could be divided into burnable, compostable, and non-compostable (glass, metal) matter. Each type of waste should be disposed in places appropriate for that type. A simple incinerator (e.g. two metal barrels connected with a grating between them) could be used for waste reduction.

4. Persons staying in $\mathrm{Ny}$-Ålesund for longer time periods should be instructed on how to minimise impact on the fragile tundra environment.

Acknowledgements. - Sincere gratitude is expressed to Odd Rogne and Jan Holtet for inviting me to undertake this project, and for the opportunity to work in conjunction with Norsk Polarinstitutt. I am greatly indebted to the personnel of Norsk Polarinstitutt for suggestions concerning my investigations, particularly Geir Gabrielsen and Fridtjof Mehlum for their help during my stays in Oslo and Ny-Ålesund. I wish to thank the staff of the $\mathrm{Ny}$-Ålesund Research Station and the station chief, Jomar Barlaup, for assisting me in the field work during the summer of 1986. I wish to thank the head of the Department of Polar Research, Institute of Ecology, Polish Academy of Sciences, Prof. St. Rakusa-Suszczewski for critical reading of this manuscript. Finally, I wish to thank Ronald Sletten for valuable help in preparing the maps and editing the text along with the reviewers. 


\section{References}

Alter, A. J. 1969: Sewerage and sewage disposal in cold regions. Cold Regions Science and Engineering Monograph III -C 5b. $107 \mathrm{pp}$.

Atlas, R. M. \& Busdosh, M. 1976: Microbial degradation of petroleum in the Arctic. Pp. 79-85 in Sharpley, J. M. \& Kaplan, A. M. (eds.): Proceedings of the Third International Biodegradation Symposium. Applied Sci. Publ. Ltd., London.

Baab, T. A. \& Bliss, L. C. 1974: Susceptibility to environmental impact on the Queen Elizabeth Island. Arctic 3, 234-236.

Baranowski, S. 1977: Subpolar glaciers of Spitsbergen and the climate of the region. Acta Univ. Wratislav. 393. Studia geograf. 31. Wroclaw. $32 \mathrm{pp}$.

Bialousz. S. \& Sklodowski. P. 1979: Class of pedology and land protection. Polit. Warszawska. Warsaw. 179 pp. (in Polish).

Bliss. L. C. 1970: Oil and the ecology of the Arctic. Trans. Roy. Soc. Can. IV, 361-372.

Bliss, L. C. \& Wein, R. W. 1972: Plant community responses to disturbance in the western Canadian Arctic. Can. J. Bot. 5. 1097-1109.

Berg, Ch. \& Wahl, E. 1982: Vernebruksplan for Ny-Alesund, Svalbard. Diplom-oppgave ved Institutt for Arkitekturhistorie. Arkikektavdelingen, Norges Tekniske Høgskole. $111 \mathrm{pp}$.

Brattbakk, I. 1981: Brøggerhalvøya Svalbard 1-8. Vegetasjonskart 1:10,000, K. Norske Vidensk. Selsk. Mus. Bot. avd., Trondheim

Budrick, J. L. \& Johnson, P. 1977: Proceedings of the Second International Symposium on cold regions engineering held at the University of Alaska. Fairbanks, 12-14 August 1976, 291368.

Cameron, J. J., Christensen, V. \& Gamble, D. J. 1977: Water and sanitation in the Northwest Territories and overview of the setting. policies and technology. North. Engineer 4, 4-12.

Chapin III. F. S. \& Shaver, G. S. 1981: Changes in soil properties and vegetation following disturbance of Alaskan Arctic tundra. J. Appl. Ecol. 18,605-617.

Doane. H. J. 1977: Environmental protection and quality enhancement in an Arctic region. Pp. 257-265 in Amaria, $P$. J., Bruneau, A. A. \& Lapp, P. A. (eds.): Arctic system. NATO Conf. Ser. Il. System Science, Plenum Press, New York.

Egan, W. A., Pavitt, R. W. \& Wiedeman, J. E. 1973: Initial plan and program. Water Supply and Waste Disposal Planning Area V - State of Alaska. State of Alaska. Office of the Governor State Planning and Research, 33-44.

Elvebakk, A. 1985: Higher phytosociological syntaxa on Svalbard and their use in subdivision of the Arctic. Nord. J. Bot. 5. 273-284.

Engelhardt, F. R. 1985: Petroleum effects in the Arctic environmens. Elsevier Appl. Sci. Publ., London, USA. 281 pp.

Falkiewicz, A. \& Kowalski, W. 1957: Land-science laboratory. Univ. Warsz., Warsaw. 234 pp. (in Polish).

Frearson, I. 1983: Public utilities in Longyearbyen. Project. 19 pp.

Getman, J. H. 1977: Arctic oil cleanup system - system requirements. Pp. 257-265 in Amaria, P. J., Bruneau, A. A. \& Lapp, P. A. (eds.): Arctic system. NATO Conf. Ser. II. System Science, Plenum Press, New York.

Golterman, H. F. 1978: Methods for physical and chemical analysis of fresh waters. IBP Handbook 8. Oxford. $213 \mathrm{pp}$.
Grainge, J. \& Shaw, J. W. 1971: Waste treatment in northern Canada. North. Engineer 4, 13-15.

Greller, A. M., Goldstein, M. \& Marcus, L. 1974: Snowmobile impact on three alpine tundra plant communities. Environ. Conserv. $1,101-110$

Hanover, N. H. 1969: Bibliography on cold regions science and technology 23. Corps of Engineers US Army Cold Regions Research and Engineering Laboratory.

Heinke, G. W. \& Deans, B. 1973: Water supply and waste disposal system for Arctic communities. Arctic 2, 149-160.

Hermanowicz, W., Dozanska, W., Dojlido, J. \& Koziorowski, B. 1976: Methods for physical and chemical analysis of water and sewage. Arkady. Warsaw. 847 pp. (in Polish).

Heuchert, K. R. 1974: Evaluation of extended acration package sewage treatment plants on the Imperial Oil Limited artificial islands Immerk and Adgo - F28. Technology programs. Sec tion Technical Branch Environmental Protection Service. Department of Environment Northwest Region, 121-158.

Ives, J. D. 1970: Arctic tundra: how fragile? A geomorphologist's point of view. Trans. Roy. Soc. Can. 8, 401-405.

Johnson, R. A. 1977: Individual wastewater treatment system in Alaska. North. Engineer 2, 29-36.

Juda, J. \& Chròsciel, S. 1974: The protection of atmospheric air. Wyd. Nauk.-Techn., Warsaw. 448 pp. (in Polish).

Klokk, T. \& Rønning, O. I. 1987: Revegetation experiments at Ny-Âlesund, Spitsbergen, Svalbard. Arct. Alp. Res. 4, 549 553.

Kaltenborn, B. P. 1986: Impacts on a high Arctic tundra, Sualbard. Dept. of Geography, Univ. of Oslo. $167 \mathrm{pp}$.

Krzyszowska, A. J. 1985: Tundra degradation in the vicinity of the Polish Polar Station, Hornsund, Svalbard. Polar Research 3 n.s., 247-252.

Krzyszowska, A. J. 1986: The balance of materials, wastes and energy of the Polish Polar Station (Hornsund, Svalbard) and the Station's effect on its immediate surroundings. Ekol. pol. $2,227-246$.

Manecki, A. 1978: Classification and mineral composition of atmospheric dust. Pr. mineral. 57, 5-17.

Markowicz, M. \& Pulina, M. 1979: Quantitative semimicroanalysis of water in carbonate karst areas. Uniw. SI. Katowice. 67 pp. (in Polish).

Moore, J. P. \& Phillips, C. R. 1975: Absorption of crude oil on arctic terrain. Chemosphere 4, 215-220.

Nowak, J. 1965: The lichens from Hornsund (SW Spitsbergen) collected during the Polish Polar Expeditions in 1957 and 1958. Fragm. Flor. et geobot. Ann. XL. 1, 171-190.

Nyholm, E. 1975-1979: Illustrated moss flora of Fennoscandia II. Musci. I-VI. Swedish Nat, Res. Counc., Lund. 799 pp.

Plichta, W. 1977: Systematics of soil of the Hornsund region, West Spitsbergen. Acta Univ. Nicolai Copernici, Ser. Geograf. XIII (43), 175-180.

Raisbeck, J. M. \& Mohtadi, M. F. 1974: The environmental impacts of oil spills on land in the Arctic regions. Water Air Soil Pollut. 2, 195-208.

Repp, K. 1979: Breerosjon, glasio-hydrologi og materialtransport $i$ et høyarktisk miljø, Brøggerbreene, Vest-Spitsbergen. Thesis, Univ. of Oslo. $12 \mathrm{pp}$.

Retningslinjer for dimensjonering av avløpserenseanlegg (revised edition), 1983. $68 \mathrm{pp}$.

Rickard, E. \& Brown, J. 1974: Effects of road vehicles on Arctic tundra. Environ. Conserv. 1, 55-62.

Rønning, O. 1. 1979: Svalbards flora. Polarhoindbok 1. Norsk Polarinstitutt, Oslo. $128 \mathrm{pp}$.

Sargent, J. W. \& Scribner, J. W. 1976: Village safe water 
projects in Alaska - case studies. North. Engineer 1, 27-30. Sextone, A. J. \& Atlas, R. M. 1977: Response of microbial population in Arctic tundra spills to crude oil. Can.J. Microb. 23, 1327-1333.

Smith, D. W. 1977: Environmental protection and quality in an Arctic region. Part 1. Environmental guide-lines and utilities delivery. Pp. 119-169 in Amaria, P. J., Bruneau, A. A. \& Lapp, P. A. (eds.): Arctic system. NATO Conf. Ser. 11. System Science, Plenum Press, New York.

Straughn, R. O. 1972: The sanitary landfill in the Subarctic. Arctic 1, 40-48.

Szerszen, L. 1965: Studies of soils of the Arctic climate zone exemplified by south-west Spitsbergen. Zesz. Nauk. Wyzsz. Szk. Roln. Wroclaw, Rolnictwo 60, 39-79.

Tedrow, J. C. F. 1973: Polar soil classification and the periglacial problem. Biul. peryglacjalny 22, 285-294.

Todd, D. K. 1970: The water encyclopedia. Washington. 559 pp
Trzosinska, A., Falkowska, L., Pecherzewski, K. \& Neugebauer, E. 1980: The chemical analysis of sea water. Handbook of the sea water chemistry. Univ. Gdansk. 147 pp. (in Polish).

Urbanski, J., Neugebauer, E. \& Sajcer, R. 1980: Physio-chemical characteristics of the waters of Horsund fjord on southwest Spitsbergen (Svalbard Archipelago) in the summer season 1979. Pol. Polar. Res, 1, 43-52.

Verstraete, W., Vanloocke, R., Berger, R. \& Verlinde, A. 1976: Modelling of the breakdown and the mobilization of hydrocarbons in unsaturated soil layers. Pp. 99-113 in Sharpley, M. \& Kaplan, A. M. (eds.): Proceedings of the Third Intern. Biodegradation Symposium. Appl. Sci. Publ. Ltd., London.

Webber, P. J. \& Ives, J. D. 1978: Damage and recovery of tundra vegetation. Environm. Conserv. 3, 171-183.

Wein, R. W. \& Bliss, L. C. 1973: Experimental crude oil spills on Arctic plant communities. J. Appl. Ecol. 3, 671-682. 